\title{
IMPACT OF BREXIT ON THE TRADE OF HUNGARIAN AGRICULTURAL AND FOOD PRODUCTS
}

\author{
MIKLÓS VÁSÁRY \\ associate professor Budapest Metropolitan University, Faculty of Business, \\ Communication and Tourism, H-1148 Budapest, Nagy Lajos Király str. 9-11. \\ mvasary@metropolitan.hu, \\ research fellow, University of Szeged, Faculty of Agriculture, H-6800 Hódmezőváráshely, \\ Andrássy str.15. mvasary@metropolitan.hu
}

\begin{abstract}
As a result of the longer preparation process, $51.9 \%$ of voters voted in the UK on 23 June 2016 in the form of a referendum to leave the European Union. Although the negotiation process has begun, many decisive points and principles - the negotiators' agreement on the post-exit process - have not decided at the beginning of 2019.

The fact that the United Kingdom officially withdraws from the European Union will significantly transform bilateral trade relations. Through the - till now - fruitful cooperation, both sides were able to take advantages and thus have achieved substantial economic benefits, economic and welfare growth. It seems that the UK has been more in need of its trade, so it is becoming increasingly important on what conditions the new cooperation will operate.

But it may also be important to see how the British exit will affect Hungary. Within this framework, one specific area of trade policy, the analysis and evaluation of agri-food processes, should be carried out. Although there is a significant geographical distance between the two countries, there has been a growing and significant commercial activity due to the favorable trade effects.

The purpose of this study is to structure the trade effects between the agri-food industry. In addition, there is a need to organize the affected branches and expected effects too.
\end{abstract}

Keywords: Brexit, agriculture, international trade

\section{INTRODUCTION}

The EU27 is the main link in the UK's agricultural trade. The United Kingdom's share of total intra-EU (i.e. internal market) imports of agri-food accounts for about 10-11\%, while the same share for exports is less than 5\% on average. (The former was 37 billion in 2017, the latter was 15 billion euro.) The UK accounts for nearly $70 \%$ of total agricultural imports from the EU27. The direct agricultural effects of Brexit are most likely to be expected in Germany, the Netherlands, France and Ireland. That is why Brexit means more in the agricultural and food industry than just reducing the risk of market loss. (EUROSTAT, 2018)

One of the most fundamental changes affecting the agricultural economy is in the conditions of sales and entry. In order to expose the problems, a summary overview of the main features of the British agri-food trade and the related trade effects is needed.

The United Kingdom's share of total intra-EU (i.e. internal market) imports of agri-food accounts for about $10-11 \%$, while the same share for exports is less than $5 \%$ on average. (In 2017, the former was $\$ 37$ billion, the latter $€ 15$ billion.) 
Table 1: United Kingdom and Hungary's share of trade within the EU (2017, Billions of Euros in food, beverages, tobacco) based on Eurostat data

\begin{tabular}{|l|r|r|r|r|r|r|}
\hline \multirow{3}{*}{\multicolumn{1}{|c|}{ Denomination }} & \multicolumn{3}{|c|}{ export } & \multicolumn{3}{c|}{ import } \\
\cline { 2 - 7 } & $\begin{array}{c}\text { Intra- } \\
\text { EU28 }\end{array}$ & $\begin{array}{c}\text { Extra- } \\
\text { EU28 }\end{array}$ & Total & $\begin{array}{c}\text { Intra- } \\
\text { EU28 }\end{array}$ & $\begin{array}{c}\text { Extra- } \\
\text { EU28 }\end{array}$ & \multirow{2}{*}{ Total } \\
\cline { 2 - 7 } & \multicolumn{4}{|c|}{ Food, beverages, tobacco } \\
\hline EU-28 billion euro & 344,1 & 121,5 & 465,6 & 341,7 & 112,0 & 453,7 \\
\hline Hungary - billion euro & 6,1 & 1,2 & 7,3 & 4,6 & 0,3 & 4,9 \\
\hline United Kingdom - billion euro & 15,1 & 10,1 & 25,1 & 37,0 & 14,9 & 51,9 \\
\hline Share of Hungary in EU28, \% & $1,8 \%$ & $1,0 \%$ & $1,6 \%$ & $1,3 \%$ & $0,3 \%$ & $1,1 \%$ \\
\hline Share of UK in EU28, \% & $4,4 \%$ & $8,3 \%$ & $5,4 \%$ & $10,8 \%$ & $13,3 \%$ & $11,4 \%$ \\
\hline
\end{tabular}

In 2000, 59.4\% of British exports to the EU (intra-EU traffic). By the end of the period, this ratio decreased to $47.8 \%$ as a result of a $19 \%$ decline. The reasons for this process should be sought primarily through the strengthening of partners and markets outside the EU. All this is the result of more effective (EU) trade policy agreements, the strengthening of the economies of the former colonies, the effects of exchange rate effects or globalization. In parallel with this process, the share of imports from the second largest importing country in the EU (after Germany and before the Netherlands) also decreased compared to the 2000 base. Looking at the balances of intra-EU trade in EU Member States, the United Kingdom's foreign trade deficit is the largest (Figure 1.).

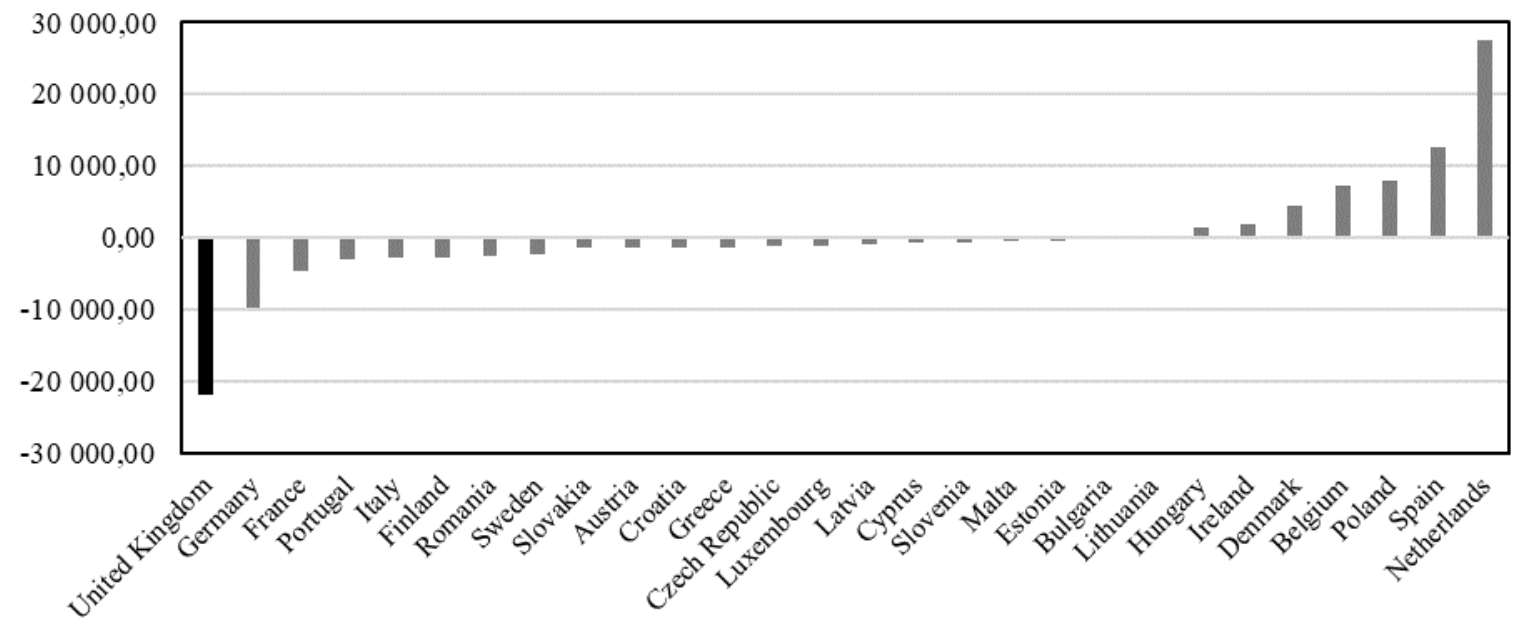

Figure 1: Trade balance of food in the EU Member States (EUR million, 2017) based on Eurostat data

UK imports of agricultural and food products have doubled over the 17 years under review, while exports of this product range have increased by only 50\%. A significant part of British foreign trade is processed products or finished products. Quantitative analysis of exports shows that bulk goods, such as cereals, represent the largest batch, but in 2017, drinks jumped to the top. The amount of other processed products is also significant. Similar products appeared in imports, along with fresh goods (meat, milk, vegetables). As the share of these product lines is decisive, countries that move to the UK can also feel the market shrinkage. According to some calculations in Germany, after the contraction of trade volume after Brexit, the production value of pork and poultry may decrease by more 
than $2 \%$, and for dairy products by more than $1 \%$. In the British relation, hundreds of millions of euros of traffic may fall. (BANSE ET AL., 2017)

Germany, the Netherlands and France are the UK's largest trading partners in the EU. Consequently, Brexit may be the most affected by these Member States. Bilateral trade of these countries with the United Kingdom accounts for $50 \%$ of the total EU27 bilateral exchange. This ranking remains unchanged for exports and imports. Only considering the agri-food trade, France and the Netherlands are the UK's main partners. Ireland will replace Germany in third place. The three major partners account for half of British imports and exports in the agro-food sector. Ireland's trade with the United Kingdom is decisive for Ireland, especially for imports: $27 \%$ of Ireland's EU imports come from the UK and $46 \%$ of total Irish food imports go to the United Kingdom. (For other European countries, this is $4 \%$ on average.) While Irish exports account for $15 \%$ of European agricultural food exports to the UK, less than 5\% of total Irish food imports.

On the basis of these, the question arises as to what effects can be prepared for Hungary?

\section{MATERIAL AND METHOD}

During the presentation of bilateral relations, I used the trade database of the European Union Statistical Office. Prior to presenting the results, the following should be underlined: for country data, the breakdown by sector and product range is based on the trade values available in the SITC (Standard International Trade Classification) and the Harmonized System (HS). (EUROSTAT, 2018)

- Due to the characteristics of the database and the limitations of its size, I analyzed the data from 2000 to 2017.

- For some commodities, the EU should be accepted as a condition for trade in goods between the EU and the EU: values do not, in many cases, indicate that the place of entry or exit in the EU and the final destination are not the same. The statistical register takes into account the place of loading, although many goods are shipped to other countries in the internal market. This unduly overrides the role of some major trading countries.

\section{RESULTS}

The value and volume of Hungarian exports to the UK is also higher than that of British imports. In terms of value, the proportion of Hungarian exports is threefold.

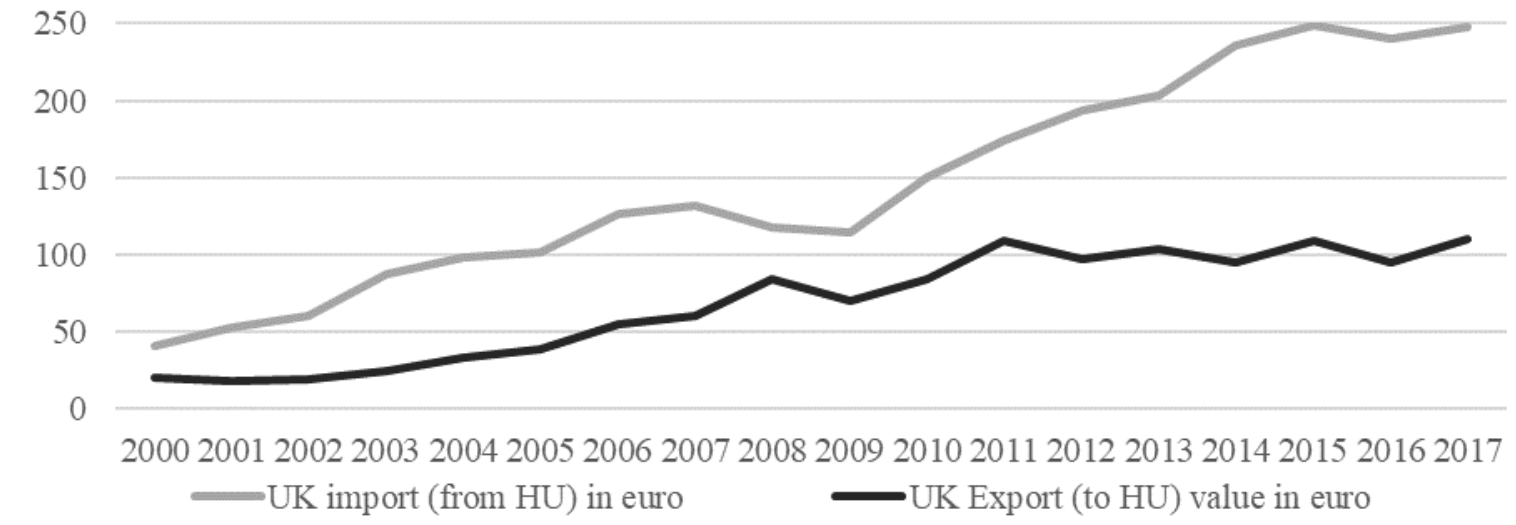

Figure 2: Development of foreign trade in agar and food industry between the United Kingdom and Hungary (2000-2017, EUR million) based on Eurostat data 
Table 2 shows the sum of the most important product ranges and Table 3 for all major product groups. Following the specifics of the Hungarian agricultural trade, it is also characteristic of the British relation: from the Hungarian side, the supply of raw materials and semi-finished products, while in the case of island products, mainly finished products, processed materials or high-value animals, animal products were imported.

Table 2.: Ten most important export and import product groups in the agri-food trade between the UK and Hungary (EUR million, 2017) based on Eurostat data

\begin{tabular}{|c|c|c|c|c|c|c|}
\hline \multicolumn{3}{|c|}{2000} & \multicolumn{4}{|c|}{2017} \\
\hline british import & \multicolumn{2}{|l|}{ british export } & \multicolumn{2}{|l|}{ british import } & \multicolumn{2}{|l|}{ british export } \\
\hline $\begin{array}{l}\text { Beverages, alcoholic } \\
\text { liquids and vinegar }\end{array}$ & 2 093,2 $2 \begin{array}{l}\text { Beverages, alcoholic } \\
\text { liquids and vinegar }\end{array}$ & 3012,0 & $\begin{array}{l}\text { Beverages, alcoholic } \\
\text { liquids and vinegar }\end{array}$ & 7052,1 & $\begin{array}{l}\text { Beverages, alcoholic } \\
\text { liquids and vinegar }\end{array}$ & 8671,4 \\
\hline $\begin{array}{l}\text { Fish and crustaceans, } \\
\text { molluscs and other } \\
\text { aquatic invertebrates }\end{array}$ & 1038,3 Meat and edible offal & 2588,5 & $\begin{array}{l}\text { Edible fruit and nuts; } \\
\text { peel of citrus fruits or } \\
\text { melons }\end{array}$ & 5636,8 & $\begin{array}{l}\text { Various edible } \\
\text { preparations }\end{array}$ & 2412,5 \\
\hline $\begin{array}{l}\text { Products made from } \\
\text { cereals, flour, starch or } \\
\text { milk; confectionery } \\
\text { products }\end{array}$ & $936,3\left[\begin{array}{l}\text { Edible vegetables and } \\
\text { some roots and tubers }\end{array}\right.$ & 1535,1 & Meat and edible offal & 4902,1 & $\begin{array}{l}\text { Fish and crustaceans, } \\
\text { molluscs and other } \\
\text { aquatic invertebrates }\end{array}$ & 2010,3 \\
\hline Meat and edible offal & $821,4 \mid \begin{array}{l}\text { Preparations of } \\
\text { vegetables, fruit, nuts } \\
\text { or other parts of } \\
\text { plants }\end{array}$ & 1446,6 & $\begin{array}{l}\text { Products of meat, fish } \\
\text { or crustaceans, } \\
\text { molluscs or other } \\
\text { aquatic invertebrates }\end{array}$ & 4043,4 & $\begin{array}{l}\text { Products made from } \\
\text { cereals, flour, starch or } \\
\text { milk; confectionery } \\
\text { products }\end{array}$ & 1906,7 \\
\hline $\begin{array}{l}\text { Dairy products; birds' } \\
\text { eggs; natural honey; } \\
\text { edible products of } \\
\text { animal origin, not } \\
\text { elsewhere specified or } \\
\text { included }\end{array}$ & $810,1 \begin{array}{l}\text { Dairy products; birds' } \\
\text { eggs; natural honey; } \\
\text { edible products of } \\
\text { animal origin, not } \\
\text { elsewhere specified or } \\
\text { included }\end{array}$ & 1430,2 & $\begin{array}{l}\text { Edible vegetables and } \\
\text { some roots and tubers }\end{array}$ & 3709,0 & $\begin{array}{l}\text { Dairy products; birds' } \\
\text { eggs; natural honey; } \\
\text { edible products of } \\
\text { animal origin, not } \\
\text { elsewhere specified or } \\
\text { included }\end{array}$ & 1899,7 \\
\hline
\end{tabular}

An overview of the individual product categories shows that in $2017,12 \%$ of tobacco and processed tobacco products, $3.9 \%$ of live animals and $3.7 \%$ of alcoholic beverages came from the United Kingdom. (Table 3)

Table 3: Proportion of agricultural and food trade between Hungary and the United Kingdom in total EU agricultural trade (EUR million, \%, 2017) based on Eurostat data

\begin{tabular}{|c|c|c|c|c|c|c|}
\hline \multirow[t]{2}{*}{ Denomination } & \multicolumn{2}{|c|}{ HU-EU28 } & \multicolumn{2}{|c|}{ HU-UK } & \multicolumn{2}{|c|}{$\begin{array}{l}\text { HU-UK trade in } \\
\text { proportion to total } \\
\text { traffic }\end{array}$} \\
\hline & import & export & import & export & import & export \\
\hline Live animals & 292.7 & 344.9 & 11.5 & 0.4 & $3.9 \%$ & $0.1 \%$ \\
\hline Meat and edible meat offal & 533.6 & 968.2 & 9.7 & 18.8 & $1.8 \%$ & $1.9 \%$ \\
\hline $\begin{array}{l}\text { Fish and crustaceans. molluscs and other } \\
\text { aquatic invertebrates }\end{array}$ & 57.9 & 28.7 & 0.3 & 0.8 & $0.5 \%$ & $2.7 \%$ \\
\hline $\begin{array}{l}\text { Dairy produce; birds' eggs; natural honey; } \\
\text { edible products of animal origin. not } \\
\text { elsewhere specified or included }\end{array}$ & 436.3 & 457.0 & 2.0 & 6.0 & $0.5 \%$ & $1.3 \%$ \\
\hline $\begin{array}{l}\text { Products of animal origin. not elsewhere } \\
\text { specified or included }\end{array}$ & 51.2 & 65.5 & 0.7 & 0.3 & $1.4 \%$ & $0.5 \%$ \\
\hline $\begin{array}{l}\text { Live trees and other plants; bulbs. roots and } \\
\text { the like; cut flowers and ornamental foliage }\end{array}$ & 104.5 & 59.1 & 0.8 & 1.4 & $0.7 \%$ & $2.4 \%$ \\
\hline $\begin{array}{l}\text { Edible vegetables and certain roots and } \\
\text { tubers }\end{array}$ & 215.9 & 277.1 & 2.4 & 24.6 & $1.1 \%$ & $8.9 \%$ \\
\hline $\begin{array}{l}\text { Edible fruit and nuts; peel of citrus fruits or } \\
\text { melons }\end{array}$ & 268.3 & 197.6 & 4.4 & 1.2 & $1.6 \%$ & $0.6 \%$ \\
\hline Coffee. tea. maté and spices & 153.2 & 55.4 & 3.4 & 1.9 & $2.2 \%$ & $3.4 \%$ \\
\hline
\end{tabular}


Review on Agriculture and Rural Development 2019 vol. 8 (1-2) ISSN $2677-0792$

\begin{tabular}{|c|c|c|c|c|c|c|}
\hline \multirow[t]{2}{*}{ Denomination } & \multicolumn{2}{|c|}{ HU-EU28 } & \multicolumn{2}{|c|}{ HU-UK } & \multicolumn{2}{|c|}{$\begin{array}{l}\text { HU-UK trade in } \\
\text { proportion to total } \\
\text { traffic }\end{array}$} \\
\hline & import & export & import & export & import & export \\
\hline Cereals & 165.7 & 1539.2 & 1.1 & 1.3 & $0.7 \%$ & $0.1 \%$ \\
\hline $\begin{array}{l}\text { Products of the milling industry; malt; } \\
\text { starches; inulin; wheat gluten }\end{array}$ & 61.9 & 106.1 & 0.3 & 0.5 & $0.6 \%$ & $0.5 \%$ \\
\hline $\begin{array}{l}\text { Oil seeds and oleaginous fruits; } \\
\text { miscellaneous grains. seeds and fruit; } \\
\text { industrial or medicinal plants; straw and } \\
\text { fodder }\end{array}$ & 269.4 & 633.6 & 1.7 & 1.3 & $0.6 \%$ & $0.2 \%$ \\
\hline $\begin{array}{l}\text { Lac; gums. resins and other vegetable saps } \\
\text { and extracts }\end{array}$ & 21.0 & 0.9 & 0.6 & 0.0 & $2.6 \%$ & $0.1 \%$ \\
\hline $\begin{array}{l}\text { Vegetable plaiting materials; vegetable } \\
\text { products not elsewhere specified or } \\
\text { included }\end{array}$ & 2.7 & 4.1 & 0.0 & 0.1 & $0.1 \%$ & $2.1 \%$ \\
\hline $\begin{array}{l}\text { Animal or vegetable fats and oils and their } \\
\text { cleavage products; prepared edible fats; } \\
\text { animal or vegetable waxes }\end{array}$ & 257.3 & 552.6 & 1.4 & 8.1 & $0.5 \%$ & $1.5 \%$ \\
\hline $\begin{array}{l}\text { Preparations of meat. of fish or of } \\
\text { crustaceans. molluscs or other aquatic } \\
\text { invertebrates }\end{array}$ & 255.8 & 274.0 & 2.1 & 35.0 & $0.8 \%$ & $12.8 \%$ \\
\hline Sugars and sugar confectionery & 190.4 & 254.7 & 0.9 & 9.1 & $0.5 \%$ & $3.6 \%$ \\
\hline Cocoa and cocoa preparations & 260.8 & 159.0 & 0.8 & 9.3 & $0.3 \%$ & $5.8 \%$ \\
\hline $\begin{array}{l}\text { Preparations of cereals. flour. starch or } \\
\text { milk; pastrycooks' products }\end{array}$ & 366.9 & 225.1 & 2.8 & 9.0 & $0.8 \%$ & $4.0 \%$ \\
\hline $\begin{array}{l}\text { Preparations of vegetables. fruit. nuts or } \\
\text { other parts of plants }\end{array}$ & 224.7 & 514.3 & 1.7 & 23.5 & $0.8 \%$ & $4.6 \%$ \\
\hline Miscellaneous edible preparations & 473.6 & 585.0 & 15.3 & 37.5 & $3.2 \%$ & $6.4 \%$ \\
\hline Beverages. spirits and vinegar & 293.9 & 645.3 & 10.8 & 13.2 & $3.7 \%$ & $2.0 \%$ \\
\hline $\begin{array}{l}\text { Residues and waste from the food } \\
\text { industries; prepared animal fodder }\end{array}$ & 443.4 & 842.4 & 5.6 & 38.2 & $1.3 \%$ & $4.5 \%$ \\
\hline $\begin{array}{l}\text { Tobacco and manufactured tobacco } \\
\text { substitutes }\end{array}$ & 243.4 & 155.4 & 29.7 & 6.3 & $12.2 \%$ & $4.0 \%$ \\
\hline Total & 5644.4 & 8945.1 & 109.9 & 247.8 & $1.9 \%$ & $2.8 \%$ \\
\hline
\end{tabular}

In imports from the United Kingdom, items with a turnover in excess of EUR 1 million, in the total imports from the EU as a whole, have a high proportion of sun-dried eastern tobacco $(95 \%)$, poultry-born female grandparents and parent breeding chicks $(92 \%)$ and $\backslash \mathrm{t}$ tobacco $(73 \%)$.

For some minor commodities, British imports were $100 \%$ in 2017 as a unit fruit jelly (jelly), fruit juice, puree and cream containing dried sugar beet, linoxin or tropical fruit containing more than $13 \%$ but not more than $30 \%$ by weight of sugar. Among the goods delivered to the EU28 market in the Hungarian exports, the highest British ratio was highest: $12.8 \%$ meat products, $8.9 \%$ edible vegetables and various edible preparations (e.g. white $6.4 \%$ of chocolate and baking powder came to the UK market. 2017. In the case of meat products, with the largest share of British exports, products containing at least $57 \%$ by weight of poultry meat or offal $(72 \%)$, with a significant proportion of white chocolate $(84 \%)$, baking powder $(59 \%)$ and candy $(50 \%)$ also the share of Hungarian exports. In addition, sweet corn, $47 \%$ of which is found in the UK, should be highlighted. A high proportion of highly processed products are also linked to the operation of multinational companies, with the characteristics of intra-industry trade. 


\section{CONCLUSION}

As a result of geographical distance, although it has increased in recent years, bilateral agricultural trade is only modest. Consequently, the direct negative effects of Brexit may be relatively modest for the Hungarian agricultural economy.

Changes in the conditions of British imports for live animals, in particular poultry breeding animals, as well as certain processed foods, alcohols, in particular distillates and whiskey, may lead to a substantial increase in import prices, and possibly a reduction in imports.

In the case of direct Hungarian exports, the biggest problems can be found in the markets for poultry meat products, food products, and processed (frozen and canned) vegetables, especially sweet corn. In addition, the export of wine and feeds, which can be considered essential for Hungarian exports, may become difficult after Brexit.

Considering the intermediary markets, Hungarian agricultural and food industry exports are expected to be significantly more indirectly affected than directly affected. Some of the Hungarian raw materials went to the British market after further processing. Therefore, the purchase and / or price of certain Hungarian agri-export products is likely to be reduced even on the short term by German, Italian, French and Dutch partners.

Due to changing circumstances, the sale of agricultural products that cannot be sold on the UK market would result in a significant additional supply. As a result, competition in the EU27 internal market can increase. Prices would decrease the consequences of competitiveness gaps would intensify. This would also have an impact on Hungarian agrifood operators.

If the current EU rules and regulations in the UK were not fully enforced, British exports would be excluded from the EU27 market. In this case, the export of domestic quality products in the domestic market could expand. At the same time, the acquisition of this market segment is possible only in fierce competition through competitive supply. New markets in Eastern Europe, the Middle East or Asia may also be needed to address market problems at the national and EU level. In doing so, it is essential to organize marketing and information campaigns promoted with national and EU support.

In the medium and long term, hopefully the British trade relations will be able to rebuild and re-export lost export markets.

\section{ACKNOWLEDGEMENTS}

The study was made with the support of the Bolyai János Research Scholarship.

\section{REFERENCES}

BAnse, M., Freund, F. (2017): Mögliche Auswirkungen eines Brexit auf den deutschen $\begin{array}{lllll}\text { Agrarhandel. Thünen } & \text { Working } & \text { Paper, } & \end{array}$ literatur.thuenen.de/digbib_extern/dn058461.pdf at 21.10. 2017

Eurostat (2018): Traditional International Trade Database Access (ComExt) epp.eurostat.ec.europa.eu/newxtweb/, at 20. March 2018.

StATISTICS NeTHERLANDS (2016), Im-, export, transit trade; value weight, http://cbs.overheidsdata.nl/82007ENG 